\title{
Problems Faced by Microcredit Borrowers in Joint Liability Groups (JLGS): Empirical Evidence of NBFC-MFIS in Uttarakhand
}

\author{
Priya Samant, Anurupa B. Singh, Ritesh Dwivedi
}

\begin{abstract}
Microcredit is proved to be an effective tool for socio-economic development of its borrowers. In the past various models took shape in developing nations and made credit/loan available at the doorstep of the borrowers. The framework for delivering credit is called credit delivery model. Joint Liability Groups (JLGs) were widely adopted by various microfinance institutions in providing credit to the borrower groups. Many studies talked about the success of JLGs but very little literature was available on the problems faced by borrowers in JLGs. Data collected from Haridwar district is used to study the problems faced by borrowers in JLGs. Relation between Group association and problems faced by borrowers was also studied. The findings show that the major problems which borrowers faced include-strict repayment schedule, Non repayment/late repayment of loan, lack of loan information, peer pressure among group members etc. There also exist a relationship between group association and problems faced by borrowers.
\end{abstract}

Index Terms: Microcredit, Joint Liability Groups, Microfinance Institutions (MFIs), Group Association, Credit delivery models

\section{INTRODUCTION}

To argue that banking cannot be done with the poor because they do not have collateral is the same as arguing that men cannot fly because they do not have wings. - Muhammad Yunus (Ghatak and Guinnane, 1999). Poverty is a condition in which a person is unable to maintain a standard of living, and is not even able to satisfy the basic necessities of food, shelter, clothes etc. 'Poverty eradication' is amongst one of the 'Millennium Development Goals (MDG)' which has gained attention from nations worldwide. Rising poverty levels has several reasons unemployment being one of them. Lack of income and employment opportunities leaves this segment of population with no choice rather than living surrendering them to adept poverty. Poverty has made wider impact on the nation's health. Lack of access to finance to the lower strata or Bottom of the pyramid (BoP) segment was one of the causes which resulted poor performance of India in Socio-Economic index (SCI).

India had strong network of formal financial institutions but it failed to make its presence amongst bottom of the pyramid. It would not be incorrect that India has two faces, one which made remarkable growth and the other which was still deprived of the finance. The need was then felt to develop an informal system to extend credit or small amount of money to the lower strata with an aim to foster income generation and employment activities. 'Microcredit' intervention proved that credit extended to the lower segment they can help them attain self dependency and explore new path to move out of poverty. The success of microcredit proved that the lower strata had immense potential and credit is a catalyst in their socio economic development. Microcredit was not only successful in reducing poverty levels in India but in many developing nations like Bangladesh, Nepal, Pakistan, Africa, Indonesia, Europe etc.

\section{MICROCREDIT DELIVERY THROUGH GROUP MECHANISM}

The structure or the framework for delivery microcredit to the borrower (or beneficiary) is known as microcredit model. As per NSSO $70^{\text {th }}$ round survey the non-institutional agencies played a significant role in advancing credit among rural households and it has presence in 19\% households in comparison to $17 \%$ by institutional agencies (Satish, 2018). Various lending methodologies have been adopted in Self Help Groups (SHGs), Joint Liability Groups (JLGs), Grameen Model etc are few to name. This paper discusses about the group-based lending models primarily the Joint Liability Groups (JLGs). Group based lending is done as (See fig 1) -

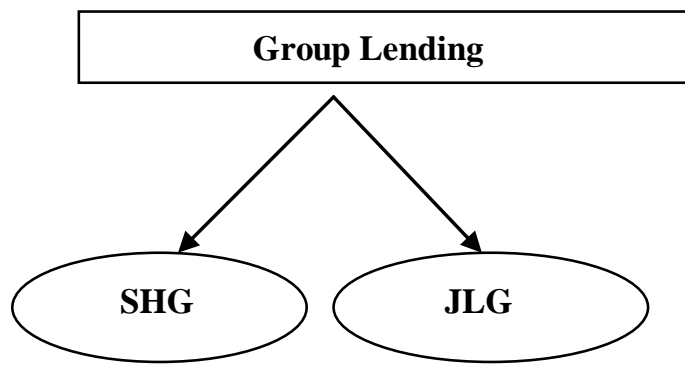

Fig.1 Group Lending 
Fig 2. Delivery Mechanism of JLG

Eminent Nobel laureate Mohd. Yunus is credited to evolve the Grameen Lending Model in Bangladesh which reached pinnacle of success in fostering socio-economic development of its borrowers (majority of which were poor women) and many other developing nations adopted this model to provide credit to low income segment ( Padma, Subryamanyam \& Ramesh, 2013). Given the underdeveloped state of empirical literature we do not say that lending via JLGs are effective like Grameen Bank. Adapting Grameen model face difficulties due to challenges posed by local conditions (Yeboah \& Oduro, 2018).

Group based lending or solidarity lending is common practice in the field of microfinance. In group lending more people come together in a group to avail the credit/loan. These people not only borrow the credit from Microfinance institutions (MFIs) but also ensure the timely repayment of the loan amount. Group lending enjoys added advantage over other forms of lending including-more people availing credit, peer pressure ensuring timely repayment, collateral free loan and is more cost effective (Padma, Subryamanyam and Ramesh, 2013). The concept of SHGs emerged in India as a project of National Bank for Agricultural and Rural Development (NABARD) on the savings and credit management of Self Help Group of MYRADA (Mysore Resettlement and Development Agency) in 1986-87 (Murugan \& Balaramurugan, 2014). (Ghosh, 2012) SHBLP was extended as a strategy for 'financial inclusion' of the poor and marginalised segment by extending making credit easily accessible in a cost-effective manner.

\section{A. JOINT LIABILITY GROUPS OR JLGs}

Those who are in need of funds and are denied credit from formal financial institutions, come together to form groups and sign the agreement in which they agree to be accountable for their loans but also for the loan of the group members, hence are named as 'Joint Liability Groups'. JLGs are 'credit oriented' and focus on taking credit at the doorstep of low income segment. In the year 2004-05 NABARD started the concept of Joint Group as a pilot project (Pareek, 2015).

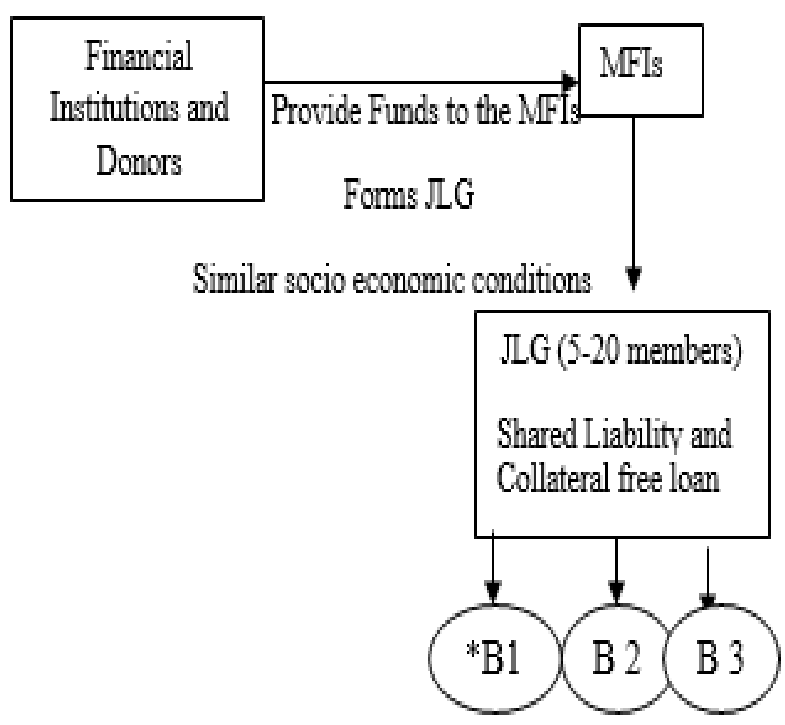

*B refers to the different borrowers in the group. So $B 1=$ Borrower 1, B2- Borrower 2, B3= Borrower 3

Figure explains the delivery mechanism of Joint liability Groups (Se Fig 2). The funds to MFIs are provided by the various funding agencies including Commercial Banks, donor institutions, International Organisations etc. with an objective of development. MFIs then form JLG comprising of 5- 20 members with similar socio economic conditions. The Group members avail collateral free loan and shared liability. Once the credit or loan amount is disbursed to the group it is then distributed amongst the borrowers.

Self Help Groups are saving based model whereas JLG model which is adopted from Grameen model of Bangladesh are credit oriented model. It views microfinance with commercial perspective (Sarma and Mehta, 2014). The major difference between the SHGs and JLGs is that in the latter the members of the group share the liability i.e. if any member does not repay the loan on time then the other group members pool the money and repay the amount. Joint Liability Models offers 'social collateral for it borrowers (Peter, 2010). In other words the members in JLG ensure that the other member makes the timely repayment of the loan amount. This ensures the better accountability and security of the MFIs involved in lending.

\section{a.Delivering Microcredit to Women through Group Lending}

Women constitute more than half of our working population but still they are considered as a second gender. The situation is deteriorating in the rural/backward areas where women are under privileged and embraced in the socio-cultural customs. The credit services of MFIs have been renowned for its ability to reach out to women and enhance their socio-economic development (Gutu, Mulugeta and Berlie, 2017).

JLGs intervention has made positive impact on livelihood of its borrowers (Srivastava \& Debabrata, 2015). Microcredit has resulted in increase in the income of the borrowers along with the improvement in their social status and higher standard of living. It has made positive impact on the education of the children, decision making, mobility, participation, social awareness and led to psychological empowerment (Mishra \& Chowbey, 2013). Microcredit has led to social empowerment and improved the living conditions of its borrowers (Vachya, 2015).

A Study by (Padmalochan, 2016) found small size of the loan to SHGs is one of the problems faced by the borrowers resulting in dissatisfaction among the group members. Delay in sanctioning the loans affected the functioning of its members. Another study of SHGs in hill station found non-cooperation among group members, lack of support from family and community organizations, also these groups were not linked with business activities and discussed loan related issues only (Murugan \& Balaramurugan, 2014). 
(Padmalochan,2016) pointed that easy and accessible way of availing credit has put extra burden on borrowers by stringent repayment pattern, as short repayment period has forced them to even sell their livestock, borrow money from the moneylenders, mortgage land etc. Also the meagre income, death of livestock, immediate need of funds etc has worsened the situation. Among the issue are lack of awareness and mutual understanding among SHG members (Padmalochan, 2016).

Credit provided to the borrowers has also encouraged many small entrepreneurs to start their source of livelihood and also generate employment. Studies have found that Clients of microcredit stated that amount of credit provided was inadequate to start any microenterprise activity and there was need of more skill development programmes by lending organizations. MFIs are adopting Group Lending as it has proven to be having strong repayment history.

\section{RESEARCH METHODOLOGY}

\section{A.NEED FOR THE STUDY}

Literature on Group lending shies away from the negative implications and other aspects of joint liability. This paper is an attempt to take up the problems faced by the borrowers in JLGs. Every coin has two faces-positive and negative. In a similar manner credit delivery through Group lending has not only led to development of the borrowers but also there have been issues which borrowers face while taking group loan. Group lending may have been successful in the countries like Bangladesh, Malaysia, South Korea, Cameroon but there are nations where there have been problems with group lending (Bhole and Ogden, 2010). These issues/problems have been merely discussed in the past. Thus in order to make JLGs sustainable it is important to understand the problems and devise the solutions. Due to negligible literature available, the study is of importance.

\section{B.OBJECTIVES OF STUDY}

The study is conducted with two objectives:

- To identify the major problems faced by the borrowers across four villages while availing the loan/credit through JLGs and to identify whether similar type of problems are faced by the borrowers.

- To find the relation between the Group association (number of years borrowers are associated with JLG) and the problems faced by the borrowers.

\section{C.CONTEXT OF STUDY}

The Haridwar district of Uttarakhand has several Non Banking Financial Companies-Micro Finance Institutions (NBFC-MFIs) actively involved in providing microcredit/loan to rural and women from marginalized sections of society with an objective of socio-economic
Although these institutions are operating in the region since many years they fail to study the problems which are faced by borrowers. In the past, few studies have been conducted () to take up this issue but the focus was on Self Help Groups (SHG). Many NBFC-MFIs are providing microcredit via JLGs which differ in approach from SHGs. Lack of empirical evidence on the problems of the borrowers this study was designed and implemented among the various NBFC-MFIs borrowers in the villages of Haridwar district of Uttarakhand.

\section{D.PARTICIPANTS AND PROCDURES}

Sampling Technique: Non Probability Sampling i.e. Convenience Sampling technique to collect the data. Four villages (Dhadeki, Bhurna, Khanpur and Tugalpur) were chosen from the two blocks of Haridwar district (two villages from each block). Our research objective focuses on the problems faced by the microcredit borrowers in Joint Liability Groups (JLGs) and due to lack of related literature we had to interact with the borrowers to explore the problems they faced while availing loan through JLGs.

Sampling Unit and Sample size: The borrowers of these villages availing credit from NBFC-MFIs via JLGs served as the sample/respondents for the present study. Since NBFC-MFIs are the second largest microcredit provider after commercial banks, particularly in the rural areas and since they have presence in all the villages so they were taken for the study. These MFIs provide loan only to the women borrowers so the sample for the research comprises of women borrowers. Each borrower served as the sampling unit for the research.

It was ensured that the purpose of the research is made clear to the respondents by explaining it to them personally and in groups. Exclusion criteria include all those borrowers availing individual loan and loan from any other institution besides NBFC-MFIs. Pilot test of the research instrument was also conducted to ensure that respondents understand what is being asked from them as majority of them were illiterate.

Sample size of 400 was taken for the study questionnaires were filled through face to face interaction with the borrowers to ensure that they understand what is being asked as many of them were illiterate. Out of the total questionnaire 362 were complete and were used for the research.

\section{DATA ANALYSIS AND FINDINGS}

For the data analysis Inferential Statistics is used. The problems which are faced by more than $40 \%$ of the respondents will be considered as the major problems. In order to accomplish the objective of the study Bivariate Analysis i.e. Cross Tabulation is used to establish the relation between the variables (Chawla,2014). For the purpose of analysis Statistical Package for Social Sciences (SPSS version 21) was used. The results of the cross tabulation are more meaningful if the cell frequencies are calculated in percentages so percentages of the cells are taken to write the findings (Chawla and Sodhi,

2014). 
Problems Faced by Microcredit Borrowers in Joint Liability Groups (JLGS): Empirical Evidence of NBFC-MFIS in Uttarakhand

Table 1. Major Problems faced by borrowers across villages

\begin{tabular}{|c|c|c|c|c|c|c|}
\hline \multirow{2}{*}{\multicolumn{2}{|c|}{ Problems faced by the Borrowers }} & \multicolumn{4}{|c|}{ Name of Village } & \multirow[b]{2}{*}{ TOTAL } \\
\hline & & \multirow{2}{*}{\begin{tabular}{l|l|} 
DHADEKI \\
53 \\
\end{tabular}} & \multirow{2}{*}{\begin{tabular}{|l|} 
BHURNA \\
68 \\
\end{tabular}} & \multirow{2}{*}{\begin{tabular}{|l|} 
KHANPUR \\
68 \\
\end{tabular}} & \multirow{2}{*}{$\begin{array}{l}\text { TUGALPUR } \\
54 \\
\end{array}$} & \\
\hline repayment & Count & & & & & 243 \\
\hline schedule & $\begin{array}{l}\text { \% within } \\
\text { Villages }\end{array}$ & $60.2 \%$ & $72.3 \%$ & $74.7 \%$ & $60.7 \%$ & \\
\hline \multirow{2}{*}{$\begin{array}{l}\text { Non-Cooperation among } \\
\text { group members }\end{array}$} & Count & 19 & 38 & 34 & 20 & 111 \\
\hline & $\begin{array}{l}\% \text { within } \\
\text { Villages }\end{array}$ & $21.6 \%$ & $40.4 \%$ & $37.4 \%$ & $22.5 \%$ & \\
\hline \multirow{2}{*}{$\begin{array}{l}\text { Presence of one lending } \\
\text { institutions unavailability } \\
\text { of lending institutions }\end{array}$} & Count & 24 & 18 & 26 & 11 & 79 \\
\hline & $\begin{array}{l}\% \text { within } \\
\text { Villages }\end{array}$ & $27.3 \%$ & $19.1 \%$ & $28.6 \%$ & $12.4 \%$ & \\
\hline \multirow{2}{*}{$\begin{array}{l}\text { Late repayment/non } \\
\text { repayment of loan by } \\
\text { group members }\end{array}$} & Count & 51 & 55 & 57 & 53 & 216 \\
\hline & $\begin{array}{l}\text { \% within } \\
\text { Villages }\end{array}$ & $58.0 \%$ & $58.5 \%$ & $62.6 \%$ & $59.6 \%$ & \\
\hline \multirow[t]{2}{*}{ Lack of family support. } & Count & 19 & 29 & 37 & 22 & 107 \\
\hline & $\begin{array}{l}\% \text { within } \\
\text { Villages }\end{array}$ & $21.6 \%$ & $30.9 \%$ & $40.7 \%$ & $24.7 \%$ & \\
\hline \multirow{2}{*}{$\begin{array}{l}\text { Peer pressure from group } \\
\text { members }\end{array}$} & Count & 34 & 38 & 42 & 36 & 150 \\
\hline & $\begin{array}{l}\% \text { within } \\
\text { Villages }\end{array}$ & $38.6 \%$ & $40.4 \%$ & $46.2 \%$ & $40.4 \%$ & \\
\hline \multirow{2}{*}{$\begin{array}{l}\text { Lack of loan related } \\
\text { information }\end{array}$} & Count & 43 & 46 & 36 & 49 & 174 \\
\hline & $\begin{array}{l}\% \text { within } \\
\text { Villages }\end{array}$ & $48.9 \%$ & $48.9 \%$ & $39.6 \%$ & $55.1 \%$ & \\
\hline \multirow{2}{*}{$\begin{array}{l}\text { Small/nsufficient loan } \\
\text { size }\end{array}$} & Count & 45 & 62 & 47 & 38 & 192 \\
\hline & $\begin{array}{l}\% \text { within } \\
\text { Villages } \\
\end{array}$ & $51.1 \%$ & $66.0 \%$ & $51.6 \%$ & $42.7 \%$ & \\
\hline \multirow{2}{*}{$\begin{array}{l}\text { Attend the group } \\
\text { meetings regularly }\end{array}$} & Count & 19 & 32 & 41 & 38 & 130 \\
\hline & $\begin{array}{l}\% \text { within } \\
\text { Villages }\end{array}$ & $21.6 \%$ & $34.0 \%$ & $45.1 \%$ & $42.7 \%$ & \\
\hline \multirow{3}{*}{$\begin{array}{l}\text { Problem due to } \\
\text { small/large size of the } \\
\text { group }\end{array}$} & Count & 10 & 31 & 34 & 20 & 95 \\
\hline & $\begin{array}{l}\% \text { within } \\
\text { problems }\end{array}$ & $10.5 \%$ & $32.6 \%$ & $35.8 \%$ & $21.1 \%$ & \\
\hline & $\begin{array}{l}\% \text { within } \\
\text { Villages }\end{array}$ & $11.4 \%$ & $33.0 \%$ & $37.4 \%$ & $22.5 \%$ & \\
\hline \multirow[t]{2}{*}{ Beharior of field staff } & Count & 3 & 17 & 17 & 4 & 41 \\
\hline & $\begin{array}{l}\% \text { within } \\
\text { Villages }\end{array}$ & $3.4 \%$ & $18.1 \%$ & $18.7 \%$ & $4.5 \%$ & \\
\hline Total & Count & 88 & 94 & 91 & 89 & 362 \\
\hline
\end{tabular}

Table 1 (a) Findings on major Problems faced by borrowers

\begin{tabular}{|c|c|c|c|}
\hline DHADEKI & BHURNA & KHANPUR & TUGALPUR \\
\hline $\begin{array}{l}60.2 \% \text { of the } \\
\text { respondents face the } \\
\text { problem of strict } \\
\text { repayment schedule. } \\
\text { Late repayment/Non } \\
\text { repayment of loan by } \\
\text { group members faced } \\
\text { by } 58 \% \text { of the } \\
\text { respondents in the } \\
\text { village. } \\
\text { Small loan size is also } \\
\text { one of the problems } \\
\text { faced by } 51.1 \% \text { of the } \\
\text { respondent. } \\
\text { Lack of loan related } \\
\text { information is another } \\
\text { issue faced } 48.9 \% \text { of } \\
\text { the respondents in the } \\
\text { village. }\end{array}$ & 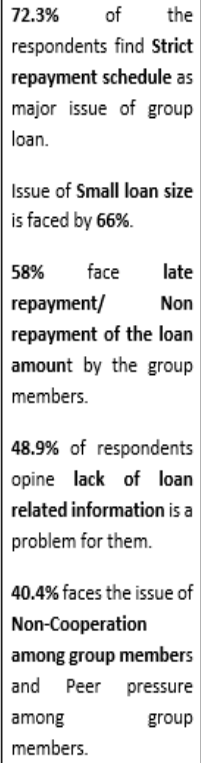 & 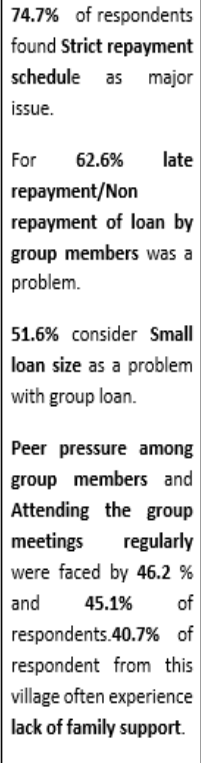 & $\begin{array}{l}60.7 \% \text { of the } \\
\text { respondents said that } \\
\text { Strict repayments } \\
\text { schedule was major } \\
\text { issue here. } \\
\text { For } 59.6 \% \text { late } \\
\text { repayment/ Non } \\
\text { repayment of the loan } \\
\text { was the problem. } \\
\text { Lack of loan related } \\
\text { information is faced by } \\
55.1 \% \text { of respondents. } \\
\text { Small loan size faced by } \\
42.7 \% \text { attending the } \\
\text { group meetings } \\
\text { regularly faced by } \\
42.7 \% \text { and Peer } \\
\text { pressure among group } \\
\text { members by } 40 \% \text { of the } \\
\text { respondents of the } \\
\text { village. }\end{array}$ \\
\hline
\end{tabular}

Table 2. Problems of borrowers having Group Association Upto 3 years

\begin{tabular}{|c|c|c|c|c|c|c|}
\hline \multirow{2}{*}{\multicolumn{2}{|c|}{ Problems faced by Borrowers }} & \multicolumn{4}{|c|}{ Name of Village } & \multirow{3}{*}{\begin{tabular}{|l} 
TOTAL \\
222
\end{tabular}} \\
\hline & & \multirow{2}{*}{$\begin{array}{l}\text { DHADEKI } \\
49\end{array}$} & \multirow{2}{*}{$\begin{array}{l}\text { BHURNA } \\
63\end{array}$} & \multirow{2}{*}{$\begin{array}{l}\text { KHANPUR } \\
57\end{array}$} & \multirow{2}{*}{$\begin{array}{l}\text { TUGALPUR } \\
53\end{array}$} & \\
\hline Strict repayment & Count & & & & & \\
\hline \multirow[t]{2}{*}{ schedule } & $\%$ within Village & $58.3 \%$ & $72.4 \%$ & $75.0 \%$ & $61.6 \%$ & \\
\hline & $\%$ of Total & $14.7 \%$ & $18.9 \%$ & $17.1 \%$ & $15.9 \%$ & $66.7 \%$ \\
\hline \multirow{3}{*}{$\begin{array}{l}\text { Non- } \\
\text { Cooperation } \\
\text { among group } \\
\text { members }\end{array}$} & Count & 19 & 36 & 27 & 19 & 101 \\
\hline & 96 within Village & $22.6 \%$ & $41.4 \%$ & $35.5 \%$ & $22.1 \%$ & \\
\hline & 96 of Total & $5.7 \%$ & $10.8 \%$ & $8.1 \%$ & $5.7 \%$ & $30.3 \%$ \\
\hline \multirow{3}{*}{$\begin{array}{l}\text { Presence of one } \\
\text { lending } \\
\text { institutions/una } \\
\text { vailability of } \\
\text { lending } \\
\text { institutions }\end{array}$} & Count & 22 & 15 & 24 & 11 & 72 \\
\hline & $\%$ within Village & $26.2 \%$ & $17.2 \%$ & $31.6 \%$ & $12.8 \%$ & \\
\hline & 96 of Total & $6.6 \%$ & $4.5 \%$ & $7.2 \%$ & $3.3 \%$ & $21.6 \%$ \\
\hline \multirow{3}{*}{$\begin{array}{l}\text { Late } \\
\text { repayment/non } \\
\text { repayment of } \\
\text { loan by group } \\
\text { members }\end{array}$} & Count & 49 & 51 & 47 & 51 & 198 \\
\hline & $\%$ within Village & $58.3 \%$ & $58.6 \%$ & $61.8 \%$ & $59.3 \%$ & \\
\hline & $\%$ of Total & $14.7 \%$ & $15.3 \%$ & $14.1 \%$ & $15.3 \%$ & $59.5 \%$ \\
\hline \multirow{3}{*}{$\begin{array}{l}\text { Lack of family } \\
\text { support }\end{array}$} & Count & 18 & 27 & 31 & 22 & 98 \\
\hline & $\%$ within Village & $21.4 \%$ & $31.0 \%$ & $40.8 \%$ & $25.6 \%$ & \\
\hline & $\%$ of Total & $5.4 \%$ & $8.1 \%$ & $9.3 \%$ & $6.6 \%$ & $29.4 \%$ \\
\hline \multirow{3}{*}{$\begin{array}{lr}\text { Peer pressure } \\
\text { from group } \\
\text { members }\end{array}$} & Count & 32 & 35 & 31 & 34 & 132 \\
\hline & $\%$ within Village & $38.1 \%$ & $40.2 \%$ & $40.8 \%$ & $39.5 \%$ & \\
\hline & $\%$ of Total & $9.6 \%$ & $10.5 \%$ & $9.3 \%$ & $10.2 \%$ & $39.6 \%$ \\
\hline \multirow{3}{*}{$\begin{array}{l}\text { Lack of loan } \\
\text { related } \\
\text { information }\end{array}$} & Count & 42 & 45 & 35 & 47 & 169 \\
\hline & $\%$ within Village & $50.0 \%$ & $51.7 \%$ & $46.1 \%$ & $54.7 \%$ & \\
\hline & $\%$ of Total & $12.6 \%$ & $13.5 \%$ & $10.5 \%$ & $14.1 \%$ & $50.8 \%$ \\
\hline \multirow[t]{3}{*}{ Small loan size } & Count & 42 & 58 & 36 & 37 & 173 \\
\hline & \% within Village & $50.0 \%$ & $66.7 \%$ & $47.4 \%$ & $43.0 \%$ & \\
\hline & $\%$ of Total & $12.6 \%$ & $17.4 \%$ & $10.8 \%$ & $11.1 \%$ & $52.0 \%$ \\
\hline \multirow{3}{*}{$\begin{array}{l}\text { Attend the group } \\
\text { meetings } \\
\text { regularly }\end{array}$} & Count & 16 & 28 & 34 & 36 & \begin{tabular}{|l|}
114 \\
\end{tabular} \\
\hline & 96 within Village & $19.0 \%$ & $32.2 \%$ & $44.7 \%$ & $41.9 \%$ & \\
\hline & 96 of Total & $4.8 \%$ & $8.4 \%$ & $10.2 \%$ & $10.8 \%$ & $34.2 \%$ \\
\hline \multirow{3}{*}{$\begin{array}{l}\text { Problem due to } \\
\text { Group Size }\end{array}$} & Count & 8 & 27 & 25 & 19 & 79 \\
\hline & $\%$ within Village & $9.5 \%$ & $31.0 \%$ & $32.9 \%$ & $22.1 \%$ & \\
\hline & $\%$ of Total & $2.4 \%$ & $8.1 \%$ & $7.5 \%$ & $5.7 \%$ & $23.7 \%$ \\
\hline \multirow{3}{*}{$\begin{array}{l}\text { Behaviour of } \\
\text { field staff }\end{array}$} & Count & 2 & 17 & 12 & 4 & 35 \\
\hline & $\%$ within Village & $2.4 \%$ & $19.5 \%$ & $15.8 \%$ & $4.7 \%$ & \\
\hline & $\%$ of Total & $0.6 \%$ & $5.1 \%$ & $3.6 \%$ & $1.2 \%$ & $10.5 \%$ \\
\hline \multirow[t]{2}{*}{ Total } & Count & 84 & 87 & 76 & 86 & 333 \\
\hline & $\%$ of Total & $25.2 \%$ & $26.1 \%$ & $22.8 \%$ & $25.8 \%$ & $100.0 \%$ \\
\hline
\end{tabular}

Table 2(a) Findings on major problems of borrowers with Group Association upto 3yrs

\begin{tabular}{|c|c|c|c|}
\hline DHADEKI & HURNA & HANPUR & UGA \\
\hline $\begin{array}{l}\text { Strict repayment } \\
\text { schedule and Late } \\
\text { repayment Non } \\
\text { repayment by group } \\
\text { members received } \\
\text { same percentage of } \\
\text { response i.e. } 58.3 \% \\
\text { respondents in the } \\
\text { village face it. } \\
\text { Similar pattern is } \\
\text { observed between } \\
\text { other two issues } \\
\text { which are Lack of } \\
\text { loan related } \\
\text { information and } \\
\text { Small loan size as } \\
\text { both received equal } \\
\text { response as faced by } \\
\text { 50\% of the } \\
\text { respondents of the } \\
\text { village. }\end{array}$ & 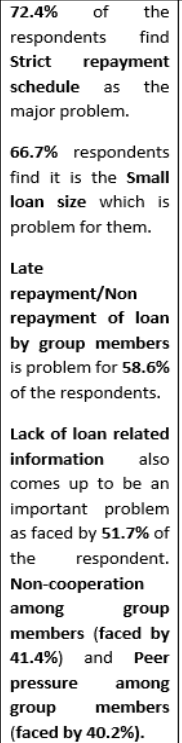 & 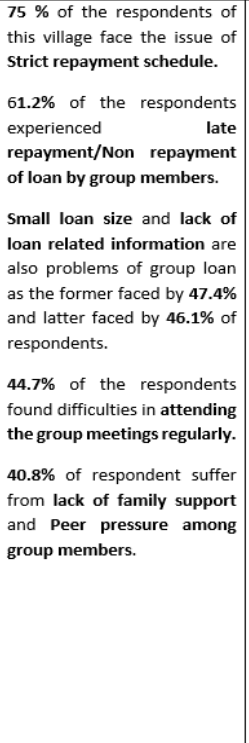 & $\begin{array}{l}61.6 \% \text { of the } \\
\text { respondents in the } \\
\text { village face the } \\
\text { problem of strict } \\
\text { repayment schedule. } \\
59.3 \% \text { of the } 4 \\
\text { respondents suffer } \\
\text { from late repayment } \\
\text { /Non repayment of } \\
\text { loan by group } \\
\text { members. } \\
54.7 \% \text { also consider } \\
\text { lack of loan related } \\
\text { information as a } \\
\text { problem of group loan. } \\
\text { Small loan size } \\
\text { and attending the } \\
\text { meetings regularly are } \\
\text { faced by } 43 \% \text { and } \\
41.9 \% \text { of respondents. }\end{array}$ \\
\hline
\end{tabular}

Published By: Blue Eyes Intelligence Engineering \& Sciences Publication 
Table 3. Major Problems of Borrowers having Group Association of more than 3 yrs

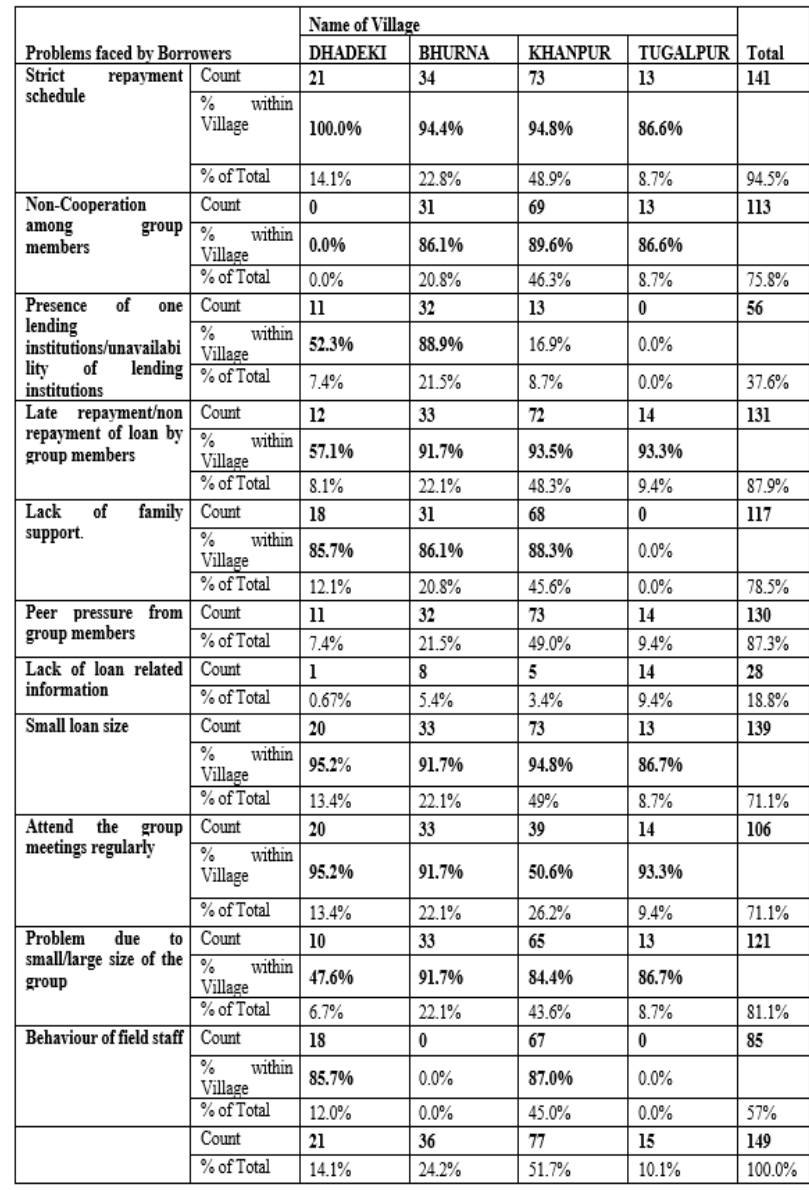

Table 3(a) Findings on problems of borrowers with Group Association > 3yrs

\begin{tabular}{|c|c|c|c|}
\hline DHADEKI & BHURNA & KHANPUR & TUGALPUR \\
\hline $\begin{array}{l}\text { Alli.e. } 100 \% \text { respondents } \\
\text { say that Strict } \\
\text { repayment schedule is } \\
\text { the major issue faced. } \\
95.2 \% \text { said Small loan } \\
\text { size and Attending the } \\
\text { meetings regularly are } \\
\text { also among the major } \\
\text { issues. } \\
\text { Equal percentage of } \\
\text { respondents i.e. 85.7\% } \\
\text { found lack of family } \\
\text { support and behaviour } \\
\text { of field staff among } \\
\text { prominent issues. } \\
57.4 \% \text { found late } \\
\text { repayment/Non } \\
\text { repayment of loan by } \\
\text { group members, as } \\
\text { problems. } \\
52 \% \text { experienced Peer } \\
\text { pressure among group } \\
\text { members and Presence } \\
\text { of one lending } \\
\text { institution/unavailabilit } \\
\text { y of lending institutions. }\end{array}$ & 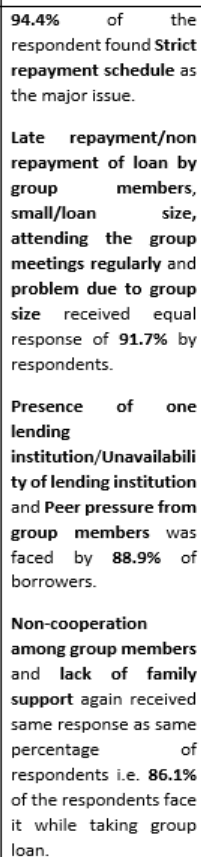 & 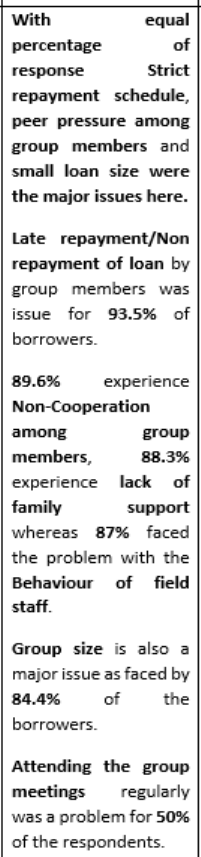 & 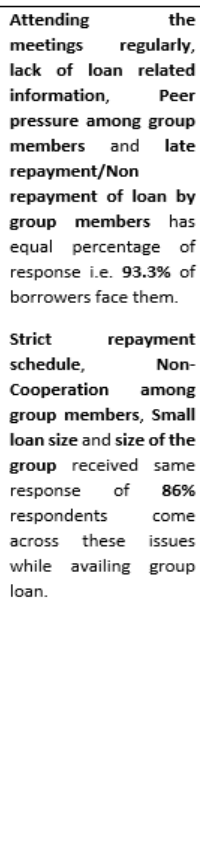 \\
\hline
\end{tabular}

\section{a. Discussion of Result}

The findings (See Table 1) for first objective have been put together (See Table 1(a)) which reveals-the major problems were-strict repayment schedule also observed by (Padmalochan, 2016), Non repayment/Late repayment of loan amount by the group members, lack of loan related information and small loan size. Non cooperation among the group members is also a problem faced by the borrowers in the group as other studies has already observed (Padmalochan, 2016; Murugan \& Balaramurugan, 2014). Peer pressure among group members and attending the group meetings regularly also appear to be the major issues of loan through JLGs. Thus Group Synergy can be harnesses in better way to make JLG lending sustainable in future. Constant follow up will give better understanding of the developmental support required by JLGs. (Srivastava and Debabrata, 2015). Group size, group dependency is one of the problems of JLGs. Non cooperation among group members weakens the group solidarity which is also an issue. Joint Liability can achieve better screening by encouraging peer monitoring and incentivise the borrowers for timely repayment of loan. Yeboah \& Oduro, 2018)

The findings (See Table $2 \&$ Table 3 ) for second objective have been put together (See Table 2(a) \& 3(a)) which provides the evidence that members with Group association up to 3 years face lesser in comparison to those having group association of more than $3 \mathrm{yrs}$.

The major with borrowers having group association up to 3 years (see Table 2(a)) were- strict repayment schedule, late repayment/Non repayment of loan by group members, lack of loan related information and small loan size. Group factors like Non cooperation among group members and peer pressure among group members are also sensitive issues which cannot be neglected while lending through groups. Lack of family support also is a major issue which a borrower face while availing loan in group, as was also found in the study by (Murugan \& Balaramurugan, 2014).

Borrowers with group association of more than $3 \mathrm{yrs}$ (see Table 3(a)) the issues were- strict repayment schedule, small loan size, presence of one lending institution/unavailability of lending institutions, group size, late repayment/non repayment by the group, lack of support of family members, peer pressure among group members, behaviour of field staff and attending the group meetings regularly. The findings suggest that on there exist a relationship between the villages based on the types of the problems faced by borrowers as similar problems permeate across four villages. Also, group association have bearing on the types of the problems, longer is the group association, more problems are faced by the borrower.

\section{CONCLUSION}

The above findings suggest that NBFC-MFIs are 'credit oriented' institutions which provide collateral free loan/credit to women borrowers via JLGs. The issues likesmall loan size, strict repayment pattern, lack of loan related information, non repayment of loan etc must be dealt with effective solutions. The findings suggest that if there is varying level of penalty or incentives for the default 
payments group model will yield higher results (Bhole and Ogden, 2010). Since women are from marginalised segment flexible repayment schedule should be implemented. So, more research investment is needed to address the borrower's problems in group lending. Group Synergy can be harnesses in better way to make JLG lending sustainable in future. Constant follow up will give better understanding of the developmental support required by JLGs. (Srivastava \& Debabrata, 2015). Loan officers should intensify the monitoring activities (Peter, 2010; Yeboah \& Oduro, 2018). Better training and supervision is required to improve loan repayment. It is important that stakeholder give equal attention to these problems. (Gutu, Mulugeta \& Berlie, 2017).

A study by (Cassar, Crowley\& Wydick, 2007) in South Africa and Armenia concluded that trust and social ties among group member are important for loan repayment. If the social ties among the group members are weak the model may not prove effective. Thus increases the cooperation among the group members and also mitigate the risk arising from the moral hazards (Peter,2010).Group members should be aware about the repayment date to reduce the default in payment by the group members as many of them depend on the credit for further investment. Follow up of loan provides incentive to repay the loan (Gine \& Karlan,2014). There is also need to monitor the group size as it size affects the access and benefits from group loans (Baland, Somanathan \& Wahhaj,2013,;Ahlin 2013). There is necessity to monitor within the groups as well (Peter, 2010). Thus, all the major problems can be put under three broad categories- Credit related problems, Group related issues and Other Problems to have better understanding

\begin{tabular}{|c|c|c|}
\hline \multicolumn{3}{|c|}{ Problems faced bv Microcredit Borrowers } \\
\hline$\nabla$ & $\downarrow$ & $\downarrow$ \\
\hline $\begin{array}{l}\begin{array}{c}\text { Credit } \\
\text { Loan } \\
\text { related } \\
\text { problems }\end{array} \\
\text { Strict } \\
\text { repayment } \\
\text { schedule } \\
\text { Lack of loan } \\
\text { related } \\
\text { information } \\
\text { Small } \\
\text { amount of } \\
\text { loan size }\end{array}$ & $\begin{array}{l}\text { Group related } \\
\text { problems } \\
\text { Non-cooperation } \\
\text { among group } \\
\text { members Late } \\
\text { repayment / Non } \\
\text { repayment of } \\
\text { loan by group } \\
\text { members, Peer } \\
\text { pressure from } \\
\text { group members } \\
\text { Attending the } \\
\text { group meetings } \\
\text { regularly Group }\end{array}$ & \begin{tabular}{l}
\multicolumn{1}{c}{$\begin{array}{c}\text { Other } \\
\text { Problems }\end{array}$} \\
Lack of \\
family \\
support \\
Presence of \\
one lending \\
institution in \\
the village \\
Behavior of \\
field staff
\end{tabular} \\
\hline
\end{tabular}

Fig 3. Problems faced by Borrowers in JLGs

result from this study are alarming as it reveals the problems while taking credit via JLG of NBFC-MFIs by the rural women of Haridwar district of Uttarakhand. There is need for follow up studies to understand the problems which the borrowers face. Nonetheless, despite the problems faced by the borrowers in availing credit via group model, there extent of socio economic development of these borrowers is encouraging. Another aspect worth taking into consideration in the future studies would be to evaluate on frequent time intervals the issues that borrowers face in group model. NBFC-MFIs should not only limit itself to extend credit as it is the primary objective of these organizations but should focus on understanding the borrower's side. The additional contribution of this study will be that it will provide MFIs to come together and adopt integrated approach in addressing the problems and devise the solutions to make JLGs sustainable in the long run and not be only seen as the methodology to merely lend credit. It should be noted that in this paper we have considered the borrowers of NBFC-MFIs. Since the previous researches have (Yeboah \& Oduro, 2018) shown that local conditions play important role in success of group lending. . Further there exists wide scope for the studies to be conducted to understand the problems of borrowers taking credit from other types of MFIs (Cooperatives, Societies, Non Governmental Organisations etc) not only under group model but also in individual lending.

\section{REFERENCES}

1. Ahlin, C. (2013). The role of group size in group lending. Journal of Development Economics, 1-51.

2. Alessandra Cassar, L. C. (2007). The Effect of Social Capital on Group Loan repayment:Evidence from Feild Experiments. The Economic Journal, 85-106.

3. Bharat Bhole, S. O. (2009). Group lending and individual lending with strategic default. Journal of Development Economics, 348-363.

4. Determinants of Loan Defaults in Some Selected Credit Unions in Kumasi Metropolis of Ghana. (2018). Open Journal of Business and Management, 778-795.

5. Edward Yeboah, I. M. (2018). Determinants of Loan Defaults in Some Selected Credit Unions in Kumasi Metropoils of Ghana. Open Journal of Business and Management, 778-795.

6. Fikadu Gutu, W. M. (2017). Determinant Factors Affecting Loan Repayment Performance of Women Borrowers from Micro Finance Institutions in Southwest Ethiopia: Evidence from Four Woredas around Gilgel Gibe Hydroelectric Power Dam. Global Journal of Management and Business Research, 43-51.

7. Ghosh, M. (2012). MIcrofinance and Rural Poverty in India: SHG Bank Linkage programme. Journal of Rural Development, 347-363.

8. Jean Marie Baland, R. S. (2013). Repayment incentives and distribution of gainsfrom group lending. Journal of Development Economics, 1-25.

9. L., V. (2015). Microfinance Livelihood Initiatives and Women Empowerment in Selected Villages of Andhra Pradesh. Journal of Rural Development, 31-48.

10. Maitreesh Ghatak, T. W. (1999). Economics of lending with joint liabilty:theory and practice. Journal of Development Economics, 195-228.

11. Peter, W. (2010). The Dynamics f Cooperation in Group Lending-A Microfinance Experiment. (pp. 1-25). Ecostor.

12. Priya Srivastava, D. S. (2015). Impact of Joint Liability Group on Sustainable Livelihoods and Social capital Promotion: A Study in Context of Bihar. International Conference on Global Economic Growth and Sustainability: Challenges and Prospects, (pp. 1-11). Mysuru, Patna.

13. Sushanta Kumar Sarma, M. H. (2014). The Best Model for Microlending:Self Help Group or Joint Liability Group? Journal of Rural Development, 247-260.

14. The Economics of Lending with Joint Liability: Theory and Practice. (1999). Journal of Development Economics, 195-228.

15. Xavier Gine, D. S. (2014). Group versus individual liability:short and long term evidence from Philippine microcredit lending groups. Journal of Development Economics, 65-83.

16. Chowbey, B. M. (2013). Study of Joint Liability Groups Problems and Prospects. Patna: Centre for Microfinance Reserach Banker's Institute of Rural development and Chandragupt Insitute of Management.

17. Deepak Chawla, N. S. (2014). Descriptive Analysis of Bivariate Data. In N. S. Deepak Chawla, Research Methodolody:Concepts and Cases (pp. 303-304). Noida: Vikas Publishing House.

18. J.Senthilvel Murugan, S. (2014). Problems of Self Help Group Members in Hill Station:Evidence through Valparai. Summer Internship Society, 12-17.

19. Padmalochan, H. (2016, January). SHG Bank Linkage Programme: A Study in Nagaon district of Assam. Assam, Assam, India. 
20. Pareek, P. (2015). "Gaon Badhe toh Desh Badhe": A Study on Joint Liability Groups (JLGs) IN North GUujarat Initiative By NABARD. ELK Asia Pacific Journals of Social Sciences, 1-8.

21. Ramesh, P. K. (2013). Joint Liability Groups : The Savior of Urban Poor. IOSR Journals of Humanities and Social Sciences.

22. Satish, P. (2018). Excluding the poor from Credit:Lessons from Andhra Pradesh and Telangana. Economic and Political weekly.

\section{AUTHORS PROFILE}

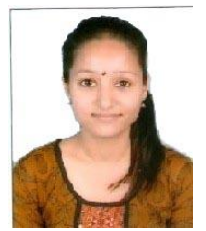

Priya Samant is a full time Research Scholar with Amity Business School, Amity University Noida. She joined the $\mathrm{PhD}$ program in the year 2015 and is working on the thesis titled 'Impact Assessment of Microcredit in state of Uttarakhand. She completed her masters (MBA) in marketing from Institute of Management Studies in 2009 , and Bachleor degree from HNB Garhwal University in 2007 from, Dehradun, Uttarakhand. Has corporate exposure as worked with Masicon Finnacial Services Ltd. Dehradun as Sales Manager. Also worked as Management Trainee in IDEA CELLULAR PVT. LTD on a project on · Analysis of Postpaid and Prepaid users of IDEA in the market' . Joined academics in the year 2009 and worked as faculty in DAAS College of Management and Technology, Dehradun. Worked as Academic Coordinator and Assistant Professor in Beehive College of Management and Technology, Dehradun. Worked as visiting faculty in Amity University and responsible for taking Behavioural Science classes for MBA,BBA,B.Tech, B.Arch,B.Ed and BBA (HM). Participated and presented research papers at various conferences at FIIB,New Delhi, Amity University, PHD House, New Delhi. Also attended various FDP at Jamia Islamia University, Delhi, Amity University,Noida. Has published research papers/case in various books, research journals and conference proceedings.

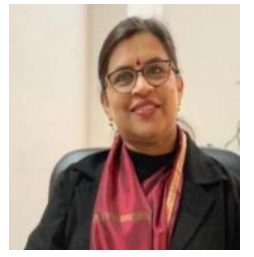

Dr. Anurupa B.Singh is working as an Associate Professor with Amity Business School, Amity University, Noida since 2011. Completed Ph.D (Marketing) in Healthcare Industry from Amity University in the year 2009 and , her master (MBA) from Magadha University, India. The different administrative positions held by her include HOD Marketing at IILM GSM Greater Noida and IILM Institute, Mentoring Program Coordinator at Amity University, Examination Coordinator at FMS and Convocation Coordinator at Amity University Noida. Also has rich Corporate experience with various organizations as Becton Dickinson India Ltd., Kendall Premium India Ltd. and Transelectra Ltd. She has published many research papers/research articles with various journals as IGI Global, International Journal of Civil Engineering and Technology, International Journal of Engineering and Technology, Journal of Advance Research in Dynamical and Control Systems and Asian Journal of multidimensional research etc. She also has research papers published in various conference proceedings at IIT Delhi, IMI Delhi, EDDI, IIM Kozhikode, AIBS Delhi, IIM Raipur and Amity Business School. Dr Singh has also in charge for various FDP/MDP MBA and PhD students at Tata Motors( Amity Business School) and International School of Management, Paris.

Dr Singh has supervised 6 doctoral thesis till date covering broad spectrum from Rural Handblock Print fabrics, Impact of CRM on satisfaction, Software product development etc. Currently she is working on 3 doctoral thesis and guiding research scholars to develop researcher's mindset.

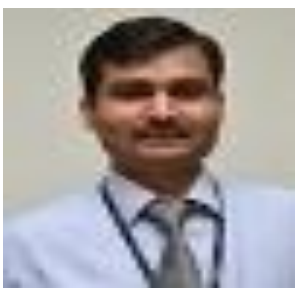

Dr. Ritesh Dwivedi is working as Rural Development and Corporate Social Responsibility Professional at Amity University, Noida, India since 2011. He completed his doctoral (Ph.D) in 'Inclusive development of Villagers' from Lucknow University in the year 2008 and his masters in Social Work (MSW) in the year 2004 from Lucknow University, India. Working as an Assistant Professor in the department of Rural Development and Social Entrepreneurship at Amity University since 2009. He is responsible to conduct classes for MBA (Rural Management), MBA(Entrepreneurship), MA (development Studies and MSW students. Has also served at HNB Garhwal University and Lucknow University as faculty member from 2006-10. Have also worked as Coordination Officer on 'Livelihood Improvement Projects for Himalayas' with Government of Uttarakhand. He was NAC Coordinator for Indo Global Social Service Society, Lucknow. Dr Singh has participated in various FDP/MDPs at institutions like
IRMA, (Gujarat) ,IGSSS (Uttar Pradesh), LIPH Uttarakhand, etc. Dr Dwivedi has to his credit 34 research papers/articles/cases published in various journals as Prabandhan:IIMS Journal of Management, Management Insight, Parivartan Journal of OIM Vashi, The Social Ion,JIS Management Vista, International Journal of Rural Studies, International Journal of Multidisciplinary Research in Social Management Sciences and many others.

Dr.Dwivedi has also been in charge for organizing and facilitating various training workshops on various social/management issues. He is member of Microfinance Community established under Solution Exchange Programme of UNDP since 2010 and Board member of an NGO SAMARTH based in Lucknow. With his wide knowledge in the field of social issues he is guiding many students to bring out with innovative strategies and solutions for various developmental issues. 